\title{
TIGRIDIA GRACIELAE (TIGRIDIEAE: IRIDACEAE), A NEW SPECIES
} FROM MEXICO

\author{
Aarón Rodríguez and Luis Ortiz-Catedral \\ Departamento de Botánica y Zoología, Universidad de Guadalajara, \\ Apartado postal 139, 45101 Zapopan, Jalisco, México
}

\begin{abstract}
Tigridia gracielae (Tigridieae: Iridaceae), from the state of México, is a new species morphologically similar to $T$. venusta, from the state of Michoacán. Tigridia gracielae differs from $T$. venusta in having shorter and narrower tepals, a longer staminal column, anthers fertile along their full length and shorter style branches. Both species share habitat preference for the shaded understory of fir and pine forests near $3000 \mathrm{~m}$ elevation.

Keywords: Iridaceae, Mexico, new species, Tigridia.

\section{RESUMEN}

Tigridia gracielae (Tigridieae: Iridaceae), del Estado de México, es una nueva especie morfológicamente similar a $T$. venusta, de Michoacán. La primera se distingue de la segunda por presentar tépalos más cortos y angostos, columna más larga, anteras fértiles en toda su longitud y ramas del estilo más cortas. Ambas especies crecen en el estrato inferior de bosques de oyamel y pino a una altitud cercana a los $3000 \mathrm{~m}$.

Palabras clave: Iridaceae, México, nueva especie, Tigridia.
\end{abstract}

\section{INTRODUCTION}

Tigridia Juss. is a New World genus of about 45 species, growing in Bolivia, Ecuador, Guatemala, Mexico and Peru (Henrich \& Goldblatt, 1994; Goldblatt et. al., 1998). In Mexico, it is represented by about 36 species and six subspecies, of which 29 species and six subspecies are endemic. Tigridia is taxonomically difficult, since many species have been described based on herbarium material. In this condition, the floral characters useful to define species boundaries are poorly preserved, making analysis of the specimens problematic.

A collecting trip in August 2002, designed to further understand this group of plants in the wild, provided us the opportunity to collect a small Tigridia near the border between the states of México and Michoacán. Initially, the specimens were identified as Tigridia venusta Cruden due the proximity of the type locality of this 
taxon and the strong similarity in habitat and morphological traits, especially those of floral color pattern. However, a detailed analysis of other floral characters has led us to conclude that the plants belong to an undescribed species for which we propose the following:

Tigridia gracielae Aarón Rodr. \& L. Ortiz-Catedral, sp. nov. (Fig. 1; Fig. 2A)

Type: México: Estado de México, municipio de San Felipe del Progreso, entre Puente de Tierra y Las Palomas, cerca a Cevati (sic) y la línea estatal entre el Estado de México y Michoacán, 1941'47.5" N, 100¹3'06" W, 3003 m, bosque de pino y oyamel, 24.VIII.2002. A. Rodríguez, L. Ortiz-Catedral y J. Cortés-Aguilar 3037 (holotype: IBUG; isotypes: IEB, MEXU).

Herba perennis, erecta, bulbosa; caules $40-50 \mathrm{~cm}$ alti, in spatha terminati, bulbus ovoideus $3-3.5 \mathrm{~cm}$ longus et $1.2-2 \mathrm{~cm}$ latus, tunicis externis tenuibus castaneis; folia basalia nulla, folia caulina bina, linearia, primum $31-40 \mathrm{~cm}$ longum, 1-1.5 cm latum, postremum brevius, $11-15.5 \mathrm{~mm}$ longum, 5-6 mm latum; rhipidium $5.5 \mathrm{~cm}$ longum, spathae subaequales, externa $4 \mathrm{~cm}$ longa et $4 \mathrm{~mm}$ lata, interna brevior, $3.5 \mathrm{~cm}$ longa et $4 \mathrm{~mm}$ lata; pedicelli gracillimi erecti, $4 \mathrm{~cm}$ longi, in fructu dilatati; flores plures, erecti, tepala conniventia et ad basim cupulam non profundam formantia, cupula alba atropurpureo maculata; tepala externa ovato-elliptica, acutata, parte basali concava, eburnea, atropurpureo maculata, parte ultra cupulam patenter atropurpurea, $19 \mathrm{~mm}$ longa et $8 \mathrm{~mm}$ lata; tepala interna unguiculata, concava, ovata, acutata, eburnea, atropurpureo maculata, $11 \mathrm{~mm}$ longa et $3.5 \mathrm{~mm}$ lata; glandula alba ad tepalorum partem basalem posita, cordata; filamenta connata, $10 \mathrm{~mm}$ longa; antherae liberae oblongae, ascendentes, tota longitudine fertiles, $6.4 \mathrm{~mm}$ longae; styli ramuli $5 \mathrm{~mm}$ longi, bipartiti, ad apicem declinati, eburnei; mucro in sinubus styli ramorum instructum; ovarium $6 \mathrm{~mm}$ longum; capsula oblongo-clavata $1.5 \mathrm{~cm}$ longa; semina ignota.

Erect perennial bulbous herb; stems $40-50 \mathrm{~cm}$ tall at anthesis; bulbs ovoid, 3-3.5 cm long, $1.2-2 \mathrm{~cm}$ wide; bulb scales chestnut colored; basal leaves none; cauline leaves 2 , linear, the lower $31-40 \mathrm{~cm}$ long, $1-1.5 \mathrm{~cm}$ wide, the upper reduced, 11-15.5 mm long, 5-6 mm wide; inflorescence a rhipidium, $5.5 \mathrm{~cm}$ long; spathes unequal, the outer one $4 \mathrm{~cm}$ long and $4 \mathrm{~mm}$ wide, the inner one shorter, $3.5 \mathrm{~cm}$ long and $4 \mathrm{~mm}$ wide; pedicels erect, $4 \mathrm{~cm}$ long, longer in fruit; flowers erect, slightly bowl-shaped; tepals connivent at base; outer tepals ovate-elliptic, acute, concave at base, cream colored with dark purple spots, reflexed, distally dark purple, $19 \mathrm{~mm}$ long, $8 \mathrm{~mm}$ wide; inner tepals shortly unguiculate, concave, ovate, acute, marked with dark spots and stripes over a white to creamy background, $11 \mathrm{~mm}$ long, $3.5 \mathrm{~mm}$ wide; nectaries at base of inner tepals cordate, white to grayish; filaments united in a column $10 \mathrm{~mm}$ long; anthers free, oblong, ascending, fertile along their full length, $6.4 \mathrm{~mm}$ long; style branches $5 \mathrm{~mm}$ long, deeply bifid into 2 style arms slightly declined 
Rodríguez and Ortiz-Catedral: Tigridia gracielae, a new species from Mexico
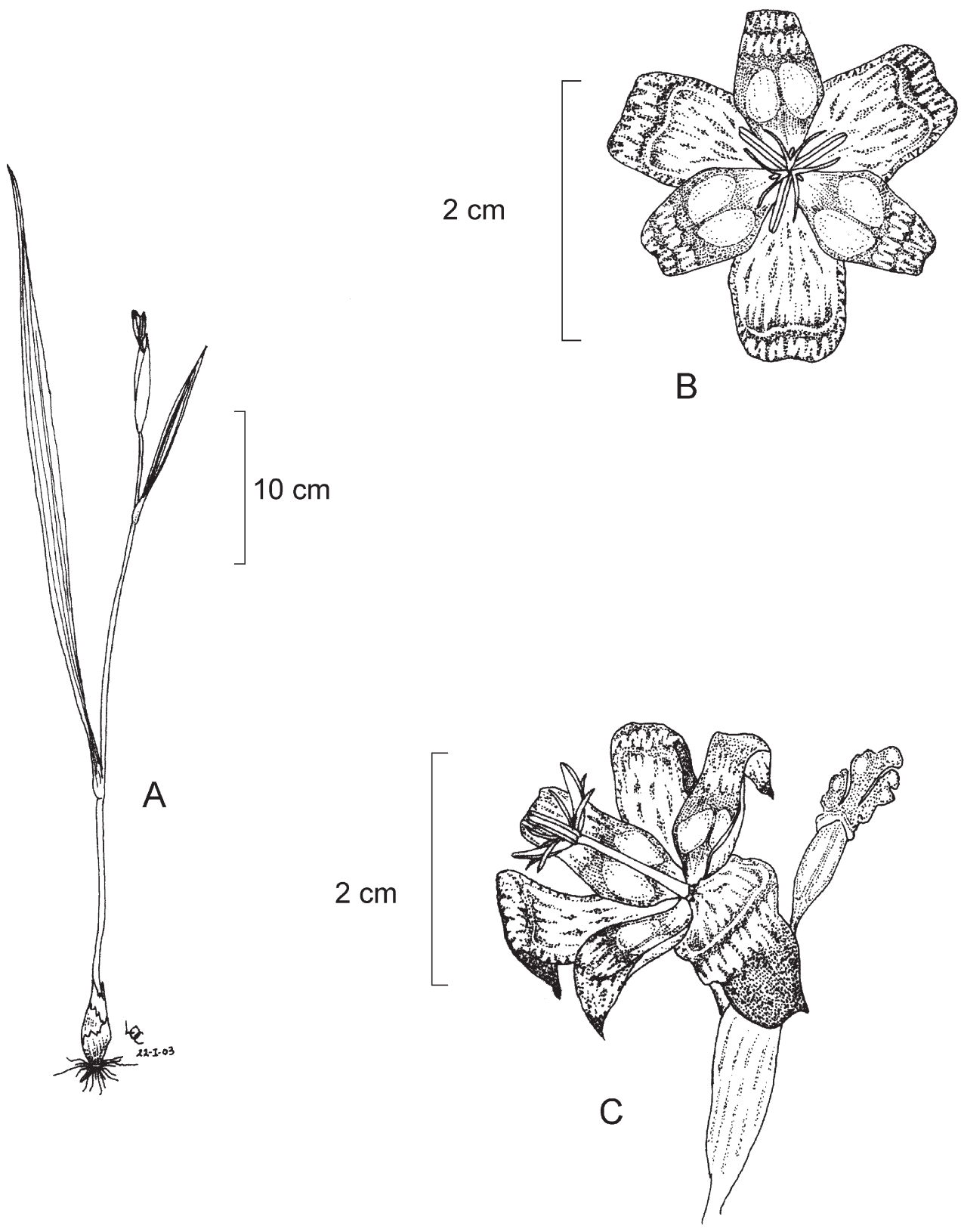

Fig. 1. Tigridia gracielae. A. habit; B. flower, frontal view; C. flower, lateral view. A-C based on the type specimen. 

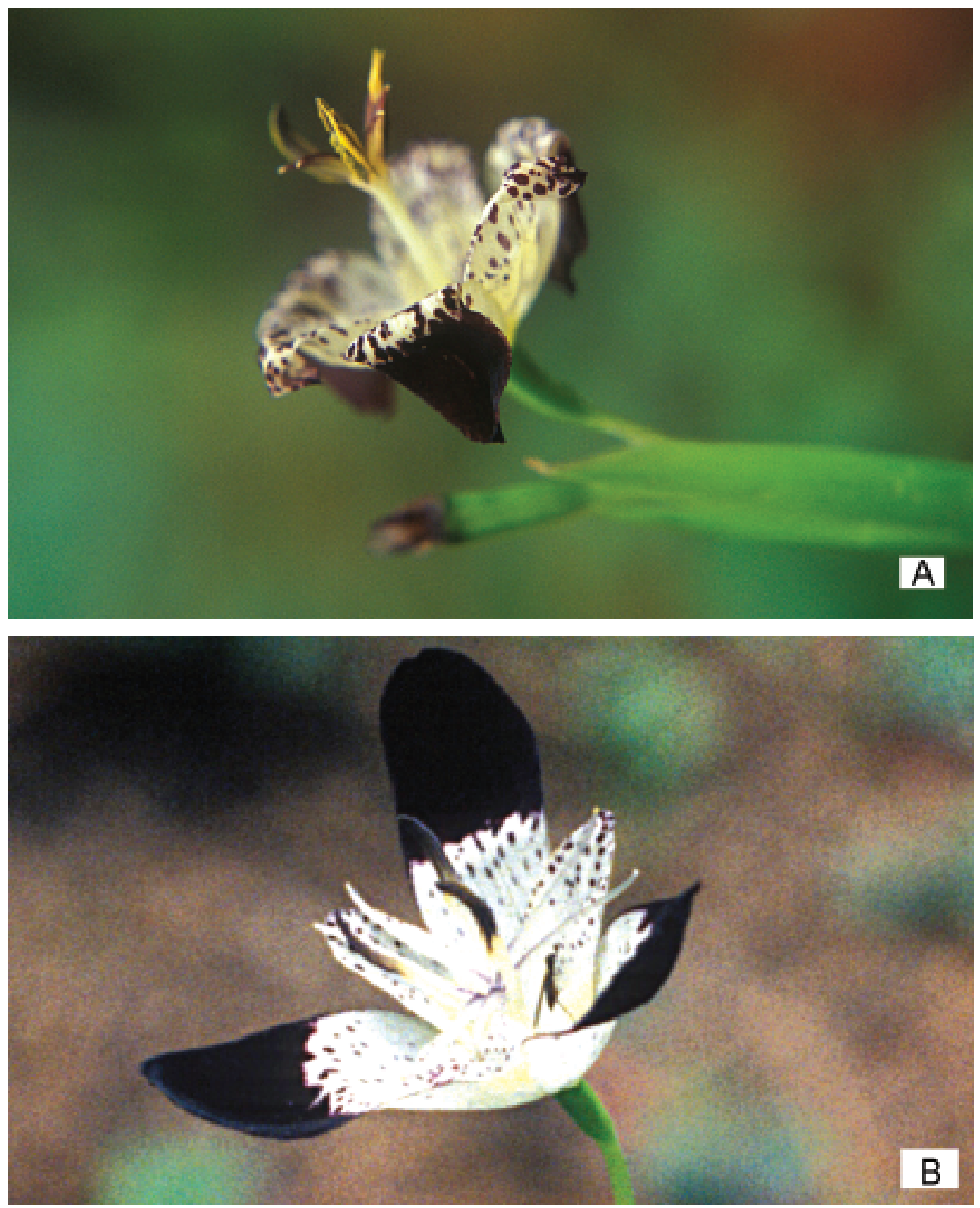

Fig. 2. A. Tigridia gracielae A. Rodríguez et al. 3037. B. Tigridia venusta A. Rodríguez et al. 2932 (pictures taken before dehydration of the plants for herbarium preservation; both specimens at IBUG). Photos by A. Rodríguez. 

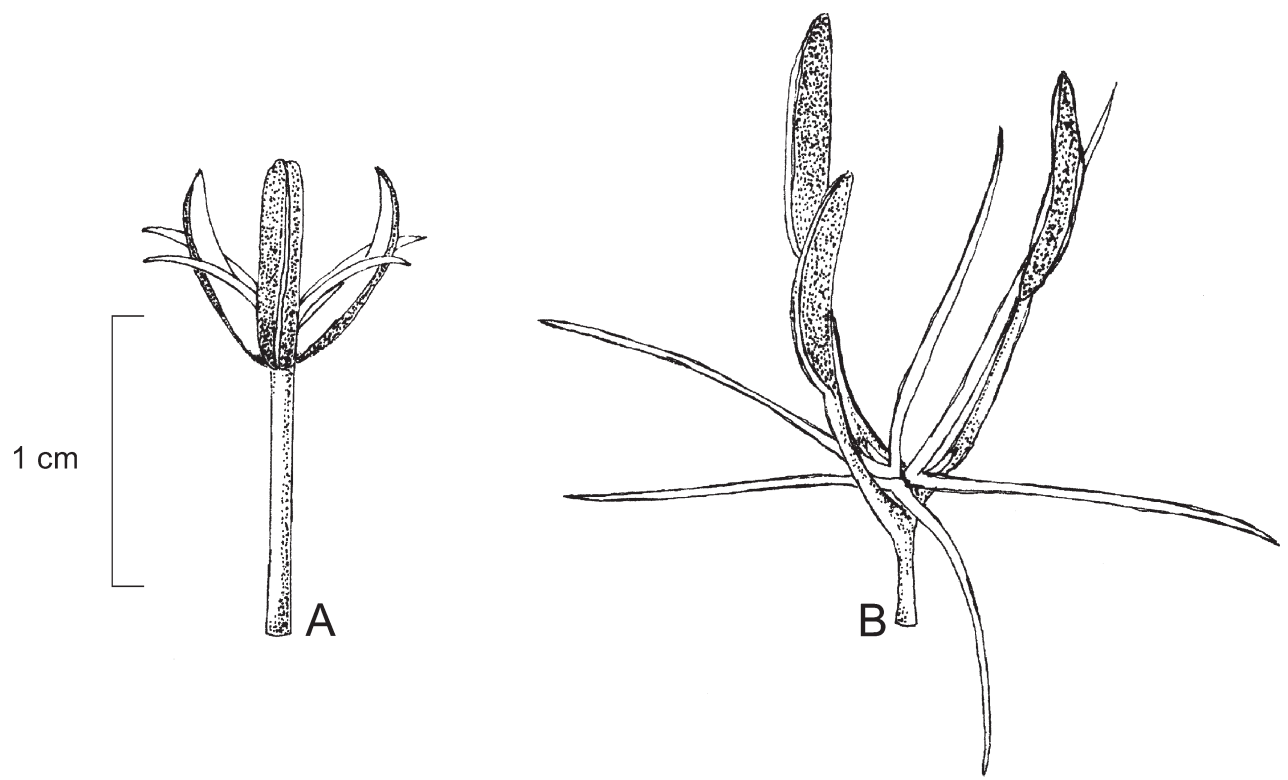

Fig. 3. Androgynoecial apparatus of A. Tigridia gracielae and B. T. venusta.

at apex, ivory colored and with a tiny mucro inserted between style arms; ovary $6 \mathrm{~mm}$ long; fruit a capsule, oblong-clavate, $1.5 \mathrm{~mm}$ long; seeds unknown.

Morphologically, Tigridia gracielae resembles $T$. venusta (Fig. 2B). The most distinctive feature of $T$. gracielae is the presence of anthers fertile along their entire length, whereas the anthers of $T$. venusta are fertile only along their distal half (Cruden, 1975). Furthermore, T. gracielae has a longer staminal column and shorter style arms (Fig. 3). A summary of the diagnostic morphological characteristics of both species is presented in Table 1.

Distribution and habitat

Tigridia gracielae is known only from the type locality. This species and $T$. venusta grow in the shaded understory of fir and pine forests near $3000 \mathrm{~m}$ elevation. The soil is predominantly claylike, black and rich in organic matter. The population consists of numerous, scattered individuals. The striking similarity in color pattern suggests that Tigridia gracielae and $T$. venusta may have common pollinators. Another species with a similar color pattern is T. potosina López-Ferrari \& Espejo (López-Ferrari \& Espejo, 2002). Additional collections and further analysis of the floral structure in Tigridia will help to understand the systematics of the group and the role of Tigridia in the ecological framework. 
Table 1. Morphological comparison between Tigridia gracielae and T. venusta.

\begin{tabular}{|l|c|c|}
\hline \multicolumn{1}{|c|}{ Character } & Tigridia gracielae & Tigridia venusta \\
\hline & & \\
Outer tepal length & $19 \mathrm{~mm}$ & $22-25 \mathrm{~mm}$ \\
Outer tepal width & $8 \mathrm{~mm}$ & $10-11 \mathrm{~mm}$ \\
Inner tepal length & $11 \mathrm{~mm}$ & $12-15 \mathrm{~mm}$ \\
Inner tepal width & $3.5 \mathrm{~mm}$ & $6-10 \mathrm{~mm}$ \\
Column length & $10 \mathrm{~mm}$ & $4-5 \mathrm{~mm}$ \\
Anther length & $6.4 \mathrm{~mm}$ & $12-13 \mathrm{~mm}$ \\
Style branch length & $5 \mathrm{~mm}$ & $9.5-11.5 \mathrm{~mm}$ \\
Anthers & fertile along & fertile only along \\
& their full length & their distal half \\
\hline
\end{tabular}

Etymology. The name honors Graciela Calderón de Rzedowski, a distinguished Mexican botanist.

\section{ACKNOWLEDGMENTS}

We thank Jesús Cortés Aguilar for his friendly support in the field. The illustrations were made by L. Ortiz-Catedral.

\section{LITERATURE CITED}

Cruden, R. W. 1975. New Tigridieae (Iridaceae) from Mexico. Brittonia 27: 103-109.

Goldblatt, P., J. C. Manning \& P. Rudall. 1998. Iridaceae. In: Kubitzki, K. (ed.). The families and genera of vascular plants. Vol. 3. Springer-Verlag. Berlin. pp. 295-333.

Henrich, J. E. \& P. Goldblatt. 1994. Iridaceae. In: Davidse, G., M. Sousa and A. Q. Charter (eds.). Flora Mesoamericana: Alismataceae a Cyperaceae. Universidad Nacional Autónoma de México, Missouri Botanical Garden and The Natural History Museum. Vol. 6. México, D.F. pp. 71-80.

López-Ferrari, A. R. \& A. Espejo. 2002. Tigridia potosina (Iridaceae: Tigridieae), una nueva especie de la Sierra de Álvarez, San Luis Potosí, México. Acta. Bot. Mex. 61: 35-40. 